\title{
On quantitative determination and mapping of seismic activity
}

\author{
J. V. RIZnichenko
}

Earthquakes beneath our feet as well as stars iu the sky occur the more often, the less their magnitude is. The laws of their distribution according to the magnitude are similar for both. In this respect a view of the night sky recalls, even quantitatively, to a seismic activity map with magnitude denotations.

Let us determine the magnitude or the size of an earthquake by means of the value of the seismic energy $E$ propagating through a sphere of a certain radius (say, $R=10 \mathrm{~km}$ ) surrounding the source. Then between the value $E$ and the number $N$ of earthquakes of various classes $K$ of the energy $E=10^{K}$ there exists a statistically established dependence $N=N(E)$ of a kind being shown in fig. 1. This graph is constructed in the double coordinate system $\log E, \log N$. It represents an approximately straight line for a wide range of energies from rather small values of about $10^{2}$ joules to about $10^{18}-10^{17}$ joules. The power number $K$ for energy representation in joules $E=10^{K}$ is the energy class of earthquakes. To precise, the class $K$ comprises earthquake energies ranging from $10^{K-0.5}$ to $10^{K+0.5}$ joules. Only for great values of $E$ a remarkable deviation from the straight line is observed, which is expressed in the strong decrease of $N$ for the most disastrous earthquakes of the world.

If the slope of the graph $N$ versus $E$ were nearly constant we should have an ability to compare the seismicity of various regions by comparing the "levels" of the graphs, wliich may be given by establishing the meaning of $N$ for a fixed $K$, for instance for $K=7$ or $K=10$. These figures $\left.N\right|_{K=7}=A_{7}$ or $\left.N\right|_{K=10}=A_{10}$ could serve a measure of seismic activity.

Thus the crucial question is whether or not the slope of the dependence between $N$ and $E$ can be considered as a constant.

The region of strong earthquakes is diseussed by Gutenberg and Richter, Kawasumi and others $\left({ }^{1}{ }^{3}\right)$. The region of weak earthquakes 
was thoroughly studied on the initiative of academician Gamburtzev $\left({ }^{4}\right)$ during the last 3 or 4 years in the Tadjik Complex Seismological Expedition of the Institute of the Earth's Physics (Academy of Sciences,

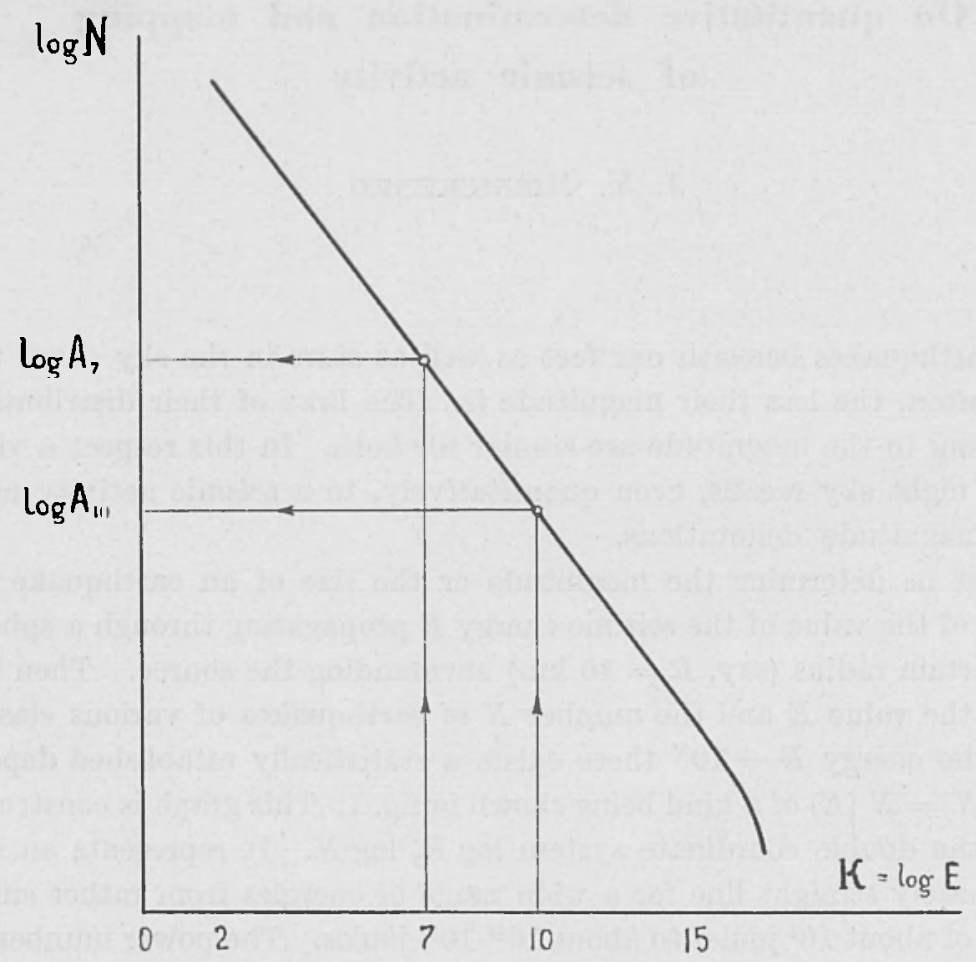

Fig. 1. - The Energy-Frequency of occurrence Graph

$$
\begin{aligned}
& \gamma=\frac{\Delta \log N}{\Delta \log E} \approx \text { const } \\
& \text { for } K-2 \div 15
\end{aligned}
$$

$N$ - frequency of occurence - a number of earthquakes of a given energy class $K=\log E$ (joules) beeng registered on a given territory $S$ within a given time interval $t$.

$A$ - seismic activity

$A_{7}$ refers to $S=100 \mathrm{~km}^{2}, t=1$ year ;

$A_{10}$ refers to $S=10.000 \mathrm{~km}^{2}, t=1$ year.

USSR) and the Seismological Institute of the Tadjik Academy of Sciences. The chief participants of this study are I. L. Nersesov and V. I. Bune. The interpretation of a mass material reveals a perfect stability of a linear law for the dependence $N=N(E)$ as it is shown in fig. 2 . 
The size of elipses on this graph corresponds to the values of the errors of $N$ and $E$ determinations. This graph has been constructed from many thousands of earthquakes being registered in the Garm region (Tadjikistan), in one of the most seismically active regions of the Soriet Union.

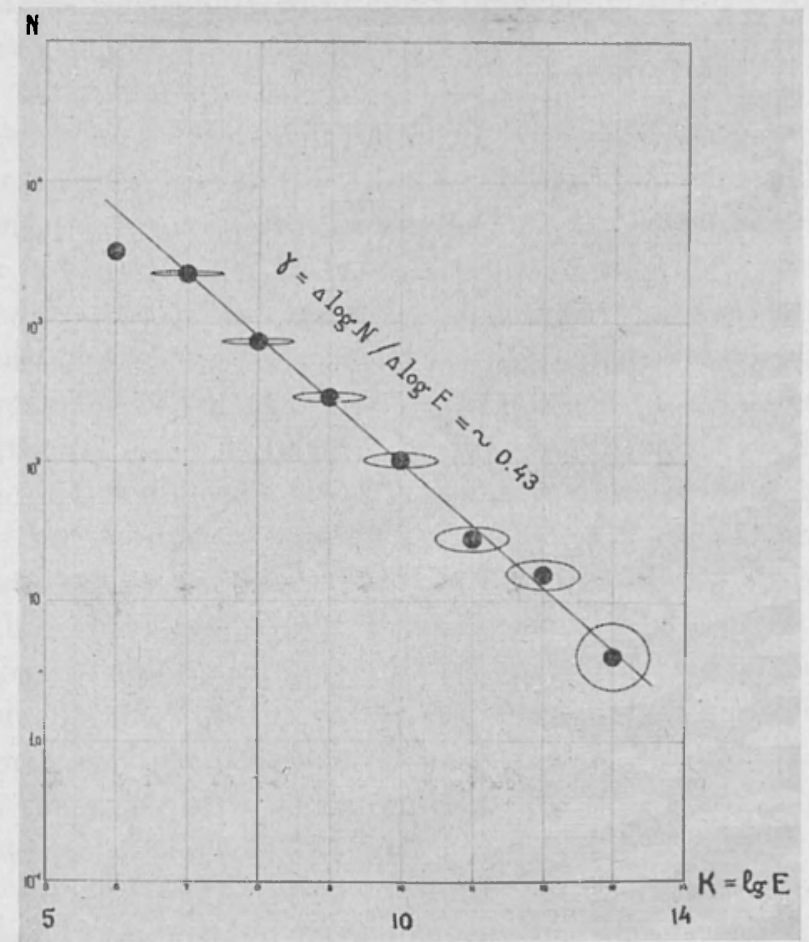

(by Nersesov, Risnichenko)

Fig. 2. - $K$-energy class of earthquake; $E=10^{K}$ joules $N$-frequency of occurrence of earthquakes Ranges of errors are shown.

Garm region, 1955-1957.

The slope $\gamma=\Delta \log N / \Delta \log E$ of the graph in the double log-coordinate system usually equals to about 0.43 for the values of $K$ varing in very large ranges from $K=2$ to $K=16$.

In fig. 3 the "occurrence graphs" for a number of regions, namely Tadjikistan, Kirgisia, Kazachstan in Central Asia; Japan; New Zealand (Tonga-Kermadek region); California (USA) and the last one for the most disastrous earthquakes of the globe (by Gutenberg and Richter) are compared. 
It is seen that the slopes of all these graphs are nearly the same, except the most strong earthquakes of the globe with the class number $K$ more than 16 or 17 .

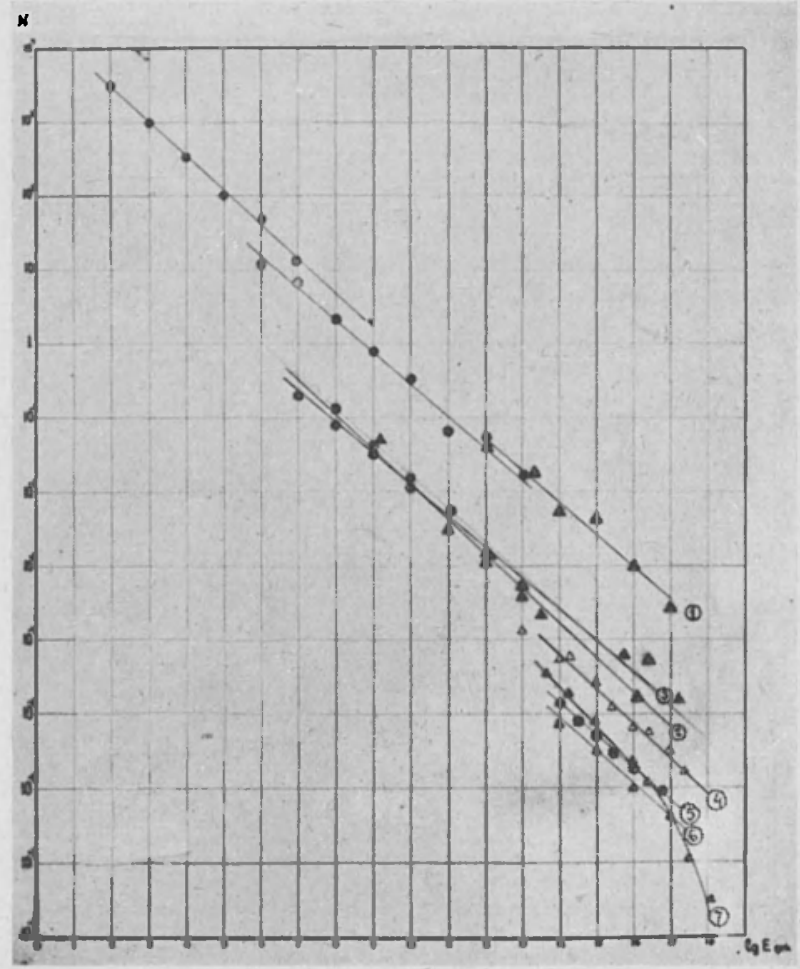

(by Nersesov)

Fig. 3 - Energy ranges: $E-10^{2} \div 10^{18}$ joules.

1 - Garm-Stalinabad (Tadjikistan); 2 - Kirgisia; 3 - Kazachstan;

4 -Japan; 5 - New Zealand; 6 -California; 7 -the Earth. $\gamma \approx$ const $N$ refers to $\mathrm{S}=100 \mathrm{~km}^{2}, t-1$ year

( 1 joul $\left.=1.00051 \times 10^{7} \mathrm{erg}\right)$.

The material of observations of the Tadjik Complex Seismological Expedition demonstrates that for usual normal seismic conditions the frequency of occurrence of earthquakes fluctuates, and the degree $R$ of the "occurrence scatter" is approximately constant:

$$
R=\sigma_{N} / N,
$$

where $N$ is the observed number of earthquakes of a given class of ener- 
gy, and $\sigma_{N}$ is the. standard deviation of this number related to the same conditions of time and space $\left(\sigma_{\%}^{*}\right.$ is the dispersion). It appeared also that for the normal seismic regime (excluding the periods of aftershocks and so on) the value of $R$ is approximately 1 . An analogous dependence of fluctuations is encountered in many branches of physics, for example, the fluctuations of weak luminous fluxes in connection with their discrete quantum microstructure.

The sense of the equation [1] for our reasoning becomes clear from a numerical example. If the number of the observed earthquakes is $N=10000$, the relative error in establishing the corresponding average frequency of occurrence is $\delta_{N}=\sigma_{N} / N .100$ per cent $=1$ per cent; if $N=$ 100 , then $\hat{o}_{N}=10$ per cent and so on. A sufficiently exact determination of the average frequency of occurrence of earthquakes requires a sufficiently great number of observations, in fact no less than some dozens. Weak earthquakes are frequent, and for them there is no difficulty in this respect. But difficulty arises in connection with strong earthquakes which are rare. However the mean frequency of occurrence of strong earthquakes can be established with a certain stability if to take into account the general law $N(E)$. Certainly it requires a great number of observations of earthquakes for a wide range of energy including especially small values of energy. It is important that such observations should not take too much time.

Thus the study of weak earthquakes is effective not only for them but for strong earthquakes as well.

Now we pass to the problem of the possible use of the frequency of earthquakes' occurrence for a quantitative representation of the regional distribution of seismic activity.

It is a along time already that seismologists are interested in the problem of a quantitative determination of seismicity. But the really constructive suggestions to the problem were made perhaps only beginning with 1953-1954. The first step was made in Netherlands by Koning $\left(^{6}\right)$. A little later it was done in some other way by Båth $\left({ }^{7}\right)$ in Sweden, Sponheuer $\left({ }^{8}\right)$ and Toperczer $\left({ }^{8}\right)$ in Germany, and other's $\left({ }^{3,10-12}\right)$. In all these studies the quantitative representation of seismicity was based directly or indirectly on the summarized sseismic energy $E$ of earthquakes or on the square roots of the energy values $\left({ }^{13,14}\right)$.

This value is known to be determined chiefly from strong earthquakes comprising the overwhelming part of the total seismic energy of earthquakes. But the strong earthquakes are rare, their numbers $N$ are small and the estimate of seismicity obtained in this way must great- 
ly fluctuate. Therefore the results of these methods are usually rather unsatisfactory as to the stability, exactness and detailed representation of the quantitative distribution pattern of seismicity.

It is quite explainable that the quantitative determination of seismicity obtained with the help of earthquakes' occurrence and based mainly on weaker earthquakes, whose numbers $N$ are great, would be much more stable.

As a measure of seismicity we suggest " seismic activity" representing the frequency of occurrence $N$ of earthquakes of a certain energy class $K$ limited by a certain area $S$ and time $t$ of observations. This value will be designated by $A .\left(^{15}\right)$.

For detailed seismic investigations a value $A=A_{7}$ is convenient for $K-7, S=100 \mathrm{~km}^{2}, T=1$ year; for regional investigations on a smaller scale, the values $A=A_{10}$ for $K=10, S=10.000 \mathrm{~km}^{2}$, and $t=1$ year are quite suitable.

The use of the frequency of earthquakes' occurrence for a quantitative determination of seismicity does not prevent from obtaining energy characteristics suggested by other authors $\left({ }^{7-9,11}\right)$; moreover, it should be noted that these characteristics may be determined more stably if taking into account the occurrence law $N(E)$, than if using direct calculations.

Thus the average density of the earthquakes' power (energy) flux may be estimated from the formula

$$
W=\left.\right|_{-\infty} ^{\infty} E N d K
$$

where $N=d n / d K, n-$ quantity of earthquakes, $N$ being approximately equal to a number of earthquakes corresponding to the energy limits $E_{1}=10^{K-0.5} ; E_{2}=10^{K+0.5}$. This formula can be used instead of that suggested by other authors $\left(^{7-8}\right)$ for the direct summation of earthquakes' energy

$$
W=\frac{1}{S t} \underset{i=1}{\stackrel{Q}{\sum}} E_{i},
$$

where $Q$ is the total number of earthquakes at the area $S$ for the time $t$.

Similarly the formula

$$
\varepsilon=i_{-\infty}^{\infty} \bar{E} N d K,
$$

based on the frequency of occurrence law allows to determine with a greater stability the so called "tectonic flow" or the "strain release" 
quantity $\left({ }^{11,12}\right)$ which is usually calculated by direct summing up according to the formula

$$
\varepsilon=\frac{1}{S t} \sum_{i=1}^{\varrho} 1 \overline{E_{i}} .
$$

If the law $N(E)$ for relative values of $N$ is supposed to be lirmly established, the values of $W$ and $\varepsilon$ from the formulas [2] and [4] can be

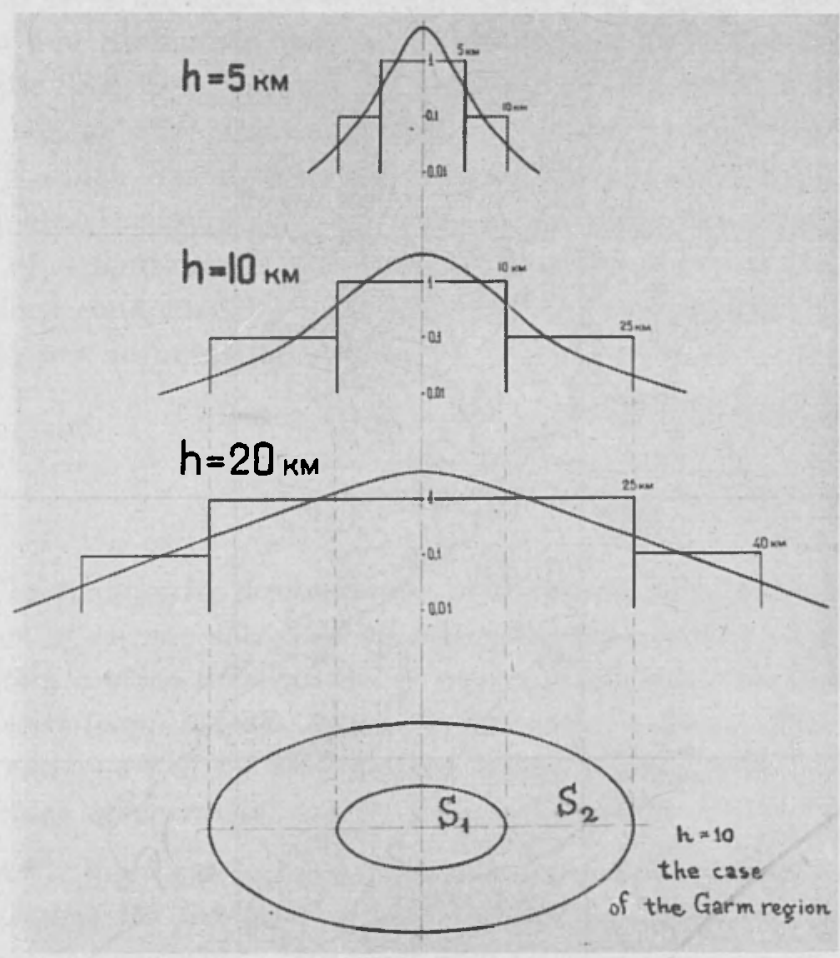

Fig. 4. - Determination of the size of the averaging region to oalculate the Seismic Activity $A$ in accordance with the seismic waves energy attenuation.

$h$ - the average depth of earthquake focus.

expressed as functions of the seismic activity $A$. The form of the law $N(E)$ is certainly to be controlled and specified proceeding from observations for each region under consideration.

When mapping the seismic activity $A$ by the suggested method it is necessary to use the observations of all earthquakes for which a sufficiently reliable estimation of the frequency of occurrence is possible. 


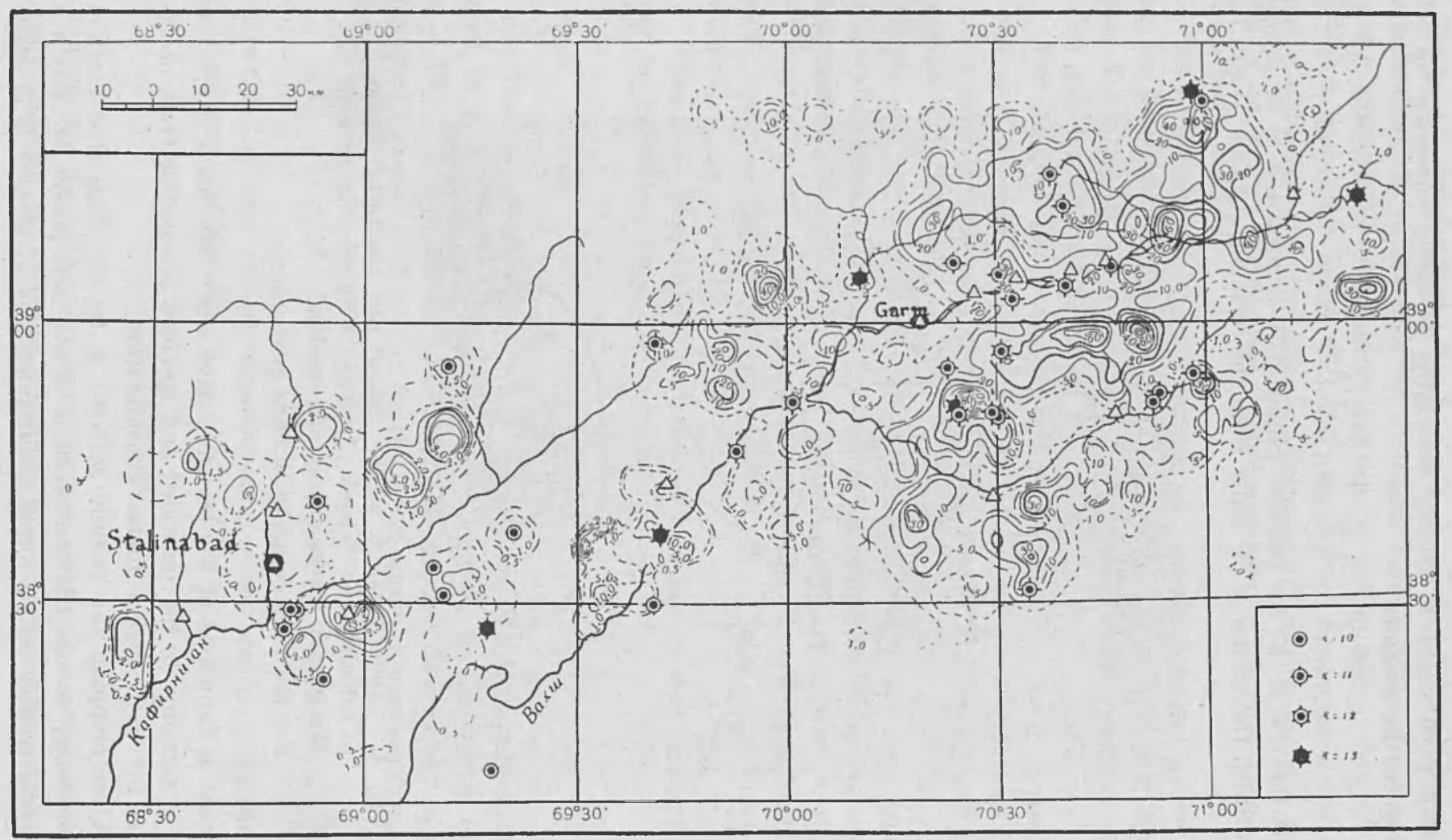

Fig. 5 - Sehematic map of the seismic activity of the Garm-Stalinabad region, 1955-1957. 
To pass from the discrete pattern of the distribution of earthquakes' epicentres of various energy classes $K$ to the smooth one, where the value of the seismic activity $A$ is represented in isolines, a method of averaging (smoothing) was applied with a sliding two-step region. The idea of its construction is shown in fig. 4. The densities of epicentres on the areas of averaging $S_{1}$ and $S_{2}$ are multiplied by factors $p_{1}$ and $p_{2}$, which decrease from the centre to the periphery.

Fig. 5 gives an example of a schematic map of the seismic activity for Garm and Stalinabad (the capital of Soviet Tadjikistan) regions of the Tadjik SSR being drawn by the method described above.

We believe that the suggested method of the representation of seismicity which has evident advantages as compared with other indicated methods may serve as a basis for mapping the seismic activity not only of separate areas but of the whole globe provided the necessary observations conducted by joint efforts of the seismologists throughout the world are accumulated.

\section{ABSTRACT}

1. The quantitative determination of seismicity being based on a direct summation of seismic energy of all the earthquakes arising on a given territory within a given time interval is scarecely applied to the detailed mapping of seismicity: it leads to widely fluctuating values. The reason is, that the main part of the total seismic energy belongs to the strong earthquakes which occur rarely.

2. As a more stable value for the quantitative representation of the average level of the frequency of occurrence of numerous earthquakes in a wide range is suggested. This level may be determined by the number of earthquakes of a given energy class, which relates to a unit space-time region. The possibility of such a determination is due to the fact of existence of an approximately stable dependence between the relative number of earthquakes and their energy.

3. In a highly seismic active Garm-Stalinabad region (Tadjilk SSR) many thousands of earthquakes, especially weak ones, have been studied by means of a net of high sensitive seismic stations. On this base a detailed seismic activity map of this region has been constructed which gives in isolines the frequency of occurrence of earthquakes on the territory under consideration. 
4. The author appeals to the seismologists of other countries to start on a systematic study of the frequency of occurrence of earthquakes of various energies, with the aim to secure the base for constructing the seismic activity map of the globe. Such a map is of great importance to solve many questions of both pure geophysical and practical interest.

\section{RIASSUNTO}

1. La determinazione quantitativa della sismicità che è stata basata sulla sommatoria diretta dell'energia sismica di tutti $i$ terremoti che si verificano su un dato territorio entro un determinato intervallo di tempo, è scarsamente applicata alla preparazione di mappe dettagliate della sismicità: essa porta a valori molto variabili. La ragione è che la maggior parte dell'energia sismica totale appartiene ai terremoti forti che si verificano raramente.

2. Si suggerisce, per un piu certo valore, una rappresentazione quantitativa del livello medio della frequenza con cui si verificano numerosi terremoti (la determinazione quantitativa di cui sopra) per un largo intervallo. Questo livello può essere determinato in base al numero di terremoti di una determinata classe di energia, che si riferisce ad una regione spazio unitario-tempo. La possibilità di una tale determinazione è dovuta al fatto dell'esistenza di una dipendenza quasi stabile tra il numero dei terremoti e la loro energia.

3. In una regione altamente attiva dal punto di vista sismico, quale quella di Garm-Stalinabad (Tadjik SSR), sono state studiate molte migliaia di terremoti, specialmente quelli di forza debole, per mezzo di una rete di stazioni sismiche ad alta sensibilità. In base ai risultati ottenuti ̀̀ stata costruita una mappa dettagliata dell'attività sismica di questa regione che dà in isolinee la frequenza con cui si verificano $i$ terremoti nella zona in esame.

4. L'A utore fa appello ai sismologi degli altri Paesi per dare inizio ad uno studio sistematico della frequenza con cui si verificano $i$ terremoti di varia forza, allo scopo di stabilire le basi per tracciare la mappa dell'attività sismica della terra. Tale mappa è di grande importanza per risolvere diverse questioni di interesse sia puramente geofisico, sia pratico. 


\section{REFERENCES}

(1) Gutenberg, B., Ricimter, C., Seismicity of the Earth., Princeton Press, 1954.

(2) KaWASUMI, H., On the energy law of occurrence of Japanese earthquales, "Bull. Earthq. Res.", Inst. Tokyo Univ., 30, 4, 319-323, (1952).

(3) Бунэ, В. И., Сравнительно-энергетическая характеристика сейсничности mpех раионов Таджсикистана. "Сталинабадского, Хаитского и Товиль-Доринского ». Докл. АН Таджискои СССР, 10, 3-12 (1956).

(4) ГАмьурцев, Г. А., Состояние и перспективы работ в области прогноза землетрясении. "Бтолл. Совета по сеисмологии прп През». АН СССР, 1, 7.14 (1955).

(5) Бунэ, В. И., Опьт использования энергетических характеристик при изучегии сейсмичности Тадэсикистана. "Изв. Отд. естеств. наук АН Таджискскои СССР, вып. 23, 19-34 (1957).

${ }^{(6)}$ Koning, L. P. G., Earthquakes in relation to their geographical distribution, depth and magnitude, "Proc. Kon. Nederl. Acad. Wet." 55, (1952).

(7) ВАтн, M., Seismicity of Fennoscandia and related problems, "Gerl. Beitr. z. Geophys. ", 63, 3, (1953).

(8) Sponheuer, W., Erdbeben und Telitonik in Deutschland, "Freiberger Forschungshefte », H. C. 1953.

${ }^{(9)}$ Toperczer, M., Zur Definition der Seismizitat. Arch. Meteorol., "Geophys. und Bioklimatol. ", 5, 4, (1953).

${ }^{\left({ }^{10}\right)}$ TrapP, E., Zur praltischen Darstellung der Seismizitat. "Gerl. Beitr. z. Geophys. ", 64, 2, (1954).

(11) Ritsema, A. R., The seismicity of the Sunda Arc in space and time. "Indonesia Journ. for Natural Science ", 1-3, (1954).

(12) Amand, P. S., Two proposed measures of seismicity. "Bull. Seism. Soc. Amer. ", 46, 1, 27-45, (1956).

(13) Benioff, H., Earthquake and rock creep. "Bull. Seismol. Soc. Amer. ", 41, 1, (1951).

$\left.{ }^{14}\right)$ - Seismic evidence for crustal structure and tectonic activity. The Crust of the Earth (a Symposium). "Geol. Soc. Amer., Special Paper", 62, (1955).

(15) Ризииченско ІО. В., Од изучении сеисмического реэсима. "Известии АН СССР, сер. геофиз ". 9, (1958). 